\title{
COMMENTS
}

\section{SALES OF CORPORATE CONTROL AND THE THEORY OF OVERKILL}

People ought to look into the history of medicine a little... . I asked a doctor and student of medical history when doctors began to cure more people than they killed. He said they might reach that in another generation. ${ }^{1}$

In the controversial area of corporate conflicts of interest, the problem of whether a holder of controlling corporate shares may dispose of them at a premium has evoked more than its share of attention. Some commentators have prophesied a rule of liability of the seller for that portion of the premium allocable to the remaining shares in all cases. ${ }^{2}$ Considering the present paucity of data on possible detrimental effects of sales of control at a premium, it is the thesis of this comment that it would be economically unsound to impose liability for the premium in every case involving a sale of controlling shares. Similarly, where the premium is received in a recapitalization, there is economic justification for not imposing liability for the premium. Conceptually, the position of the owner of share control is a difficult one. In conflict with the supposed unfettered freedom to dispose of his holdings based on "habits of thought in a purchase and sale economy," 3 is the notion that minimal duties of fairness are owed to the non-controlling shareholders by those in control, as fiduciaries. ${ }^{4}$

Earlier, the courts imposed liability on the seller for the premium

$1 \mathrm{Knight,} \mathrm{Some} \mathrm{Comments} \mathrm{on} \mathrm{the} \mathrm{Assumptions} \mathrm{Underlying} \mathrm{the} \mathrm{Conflict-of-Interest}$ Concept, in CONFERENGE on Conflict of INTEREST 97-98 (U. Chi. Law School Conference Series No. 17, 1961).

92 Berle, "Control" in Corporate Law, 58 Colum. L. REv. 1212, 1220 (1958) ("slowly emerging rule (by no means universally acknowledged)"). See also Gower, THE PRINCIPLES OF MODERN COMPANy LAw 494 (2d ed. 1957) ("the American courts are beginning to come round to the view"); LATTIN, Corporations 268 (1959); cf. Leech, Transactions in Corporate Control, 104 U. PA. L. REv. 725, 839 (1956). Surprisingly, Professor Jennings, a forceful advocate of a rule imposing liability in all cases, has declined to predict the outcome. Jennings, Trading in Corporate Control, 44 CALIF. L. REv. 1, 39 (1956).

3 VeBLEN, ThE THEORY OF BusInEss ENTERPRise 77 (1923); Levy v. American Beverage Corp., 265 App. Div. 208, 218, 38 N.Y.S.2d 517, 523 (1942) ("lawful property right").

4 Pepper v. Litton, 308 U.S. 295 (1939) (subordination of claims in bankruptcy); cf. Taylor v. Standard Gas \& Elec. Co., 306 U.S. 307 (1989) (subordination of claims in a $\$ 77(\mathrm{~B})$ reorganization). 
when the transaction could be characterized as a "corporate transaction" or a "sale of office."5 At present, however, two views which lead to the imposition of liability in all cases are the focal point of repeated attention. The first, that of Professor Berle, argues from corporate democracy and the putative equality of all shareholders. ${ }^{6}$ Since control entails the power to dispose of assets of all the shareholders, the premium can be attributed to the sale of control and should be allotted to all shareholders ratably. 7

The second argument for the imposition of liability in all cases stems not from the power of control, but from:

concern over the motives of the purchaser and the type of transactions likely to follow the transfer of control. Professor Jennings ${ }^{8}$ suggests that in the usual case the purchaser's willingness to pay a premium springs from an expectation of returns which will not be shared with all shareholders, returns following from private exploitation of "corporate patronage or other nonbalance sheet assets or from diversion of profits in reorganization or liquidation."'9

5 E.g., Baker \& Cary, Cases on Corporations 591-97 (3d ed. 1959). A third category is "misrepresentation." But the situations in which controlling shareholders mislead others into selling at a lower price than that received for control, though numerous, are not within the scope of this comment. See cases collected at Annot. 50 A.L.R.2d 1146 (1956); BARER \& CARY, op. cit. supra at 595-97; 13 Fletcher, Cyclopedia of the Law of Private Corporations \& 5845 (rev. ed. 1961).

6 Berre \& Means, The Modern Corporation and Private Property 243-44 (1932), was the first exposition of this theory.

7 GowER, op. cit. supra note 2, at 494: “This seems eminently desirable . . a all members should share ratably in this, not just the lucky few. But this would be a highly novel doctrine in England." See also Short v. Treasury Commissioners, [1948] A.C. 534, 546 (dictum); cf. Young v. Higbee Co., 324 U.S. 204 (1945). In Young, the defendants, preferred shareholders, objected to confirmation of a plan of reorganization on the grounds that participation of the junior creditors was excessive and should be subordinated to the preferred. Pending the defendants' appeal, they sold their shares to directors of the corporation who were junior creditors and the appeal was voluntarily dismissed. The court held the defendants liable for the premium on the sale for the benefit of all preferred shareholders.

8 Jennings, supra note 2, at 14-19.

9 Katz, The Sale of Corporate Control, 38 Chrcago B.A. Record 376, 379 (1957). See also 1 Hornstein, Corporation Law and Practice $\$ 366$, at 479-80 (1959). A third view would impose liability for the premium as a means of preventing the controlling shares of a close corporation from being transferred in opposition to the "reasonable expectations" of other shareholders who expect to participate in the management as if it were a partnership. Comment, Sales of Corporate Control at a Premium: An Analysis and Suggested Approach, 1961 DukE L.J. 554, 561-64. This view, while novel, necessarily presumes that a significant degree of co-variation exists between sales of control, receipt of a premium and inequities in close corporations. Professors Jennings and Hornstein to the contrary notwithstanding, even a co-variation between sales of control and receipt of a premium has yet to be proven. Hill, The Sale of Controlling Shares, 70 HARv. L. REv. 986, 1038-39 n.150 (1957). Furthermore, in the case of the 
This view of Professor Jennings is subject to the criticism that removing the premium would block an unknown number of beneficial sales of control, ${ }^{10}$ thus depriving the corporation of a more efficient, rather than merely a more optimistic, management. Conceding Professor Jennings' asumption that some purchasers are willing to pay a premium to obtain benefits at the expense of remaining shareholders, there is no empirical evidence to justify his casual assumption that most purchasers of share control are actuated by such improper motives. Furthermore, the casual assumption is contrary to the economic hypothesis about the functioning of a free market for capital. For the optimal allocation of resources, "all that matters is whether the distribution of funds contributes to efficiency, and there is every reason to suppose that, broadly speaking, it does. Those firms which use funds profitably find it easy to get more; those which do not, find it difficult." 11 There is no reason why this hypothesis is not equally applicable to purchasers of controlling shares. ${ }^{12}$

Professor Berle's conclusion of liability in all cases is similarly rebuttable on the ground that an unknown number of beneficial sales resulting in more efficient management would be blocked. It is no answer to this economic argument merely to say that a "high-minded" purchaser

close corporation there exists no simple rule of thumb, such as market value, to determine whether a premium exists. On the difficulty of valuing shares in a close corporation, see generally Rice, The Valuation of Close Held Stocks: A Lottery in Federal Taxation, 98 U. PA. L. REv. 367 (1950). The author of the third view does well to suggest that the primary protection of a shareholder in a close corporation is proper draftsmanship.

10 Hill, supra note 9, at 1039; Katz, supra note 9, at 379-80; Comment, supra note 9, at 565; Comment, Sale of Corporate Control, 19 U. CHr. L. REv. 869, 870-72 (1952); Note, The Sale of Corporate Contral: The Berle Theory and the Law, 25 U. PIrT. L. REv. 59, 71 (1963); Note, Restrictions on the Transfer of Controlling Shares, 40 VA. L. Rev. 195, 208 (1954); cf. Company Law Committee, Report, CMD. No. 1749, at 98 (1962): "There appears to be general agreement that take-overs, mergers and amalgamations of companies . . . are an essential feature of economic growth and development." See also Note, Corporations: Liability for Sale of Controlling Stock: Perlman v. Feldmann, 40 CoRNeLI L.Q. 786, 794 (1955), which opposed the proposed rule of liability for the premium in all cases on the ground that "this result is repugnant to present day concepts of stock transferability ...." It is fair to assume that the alienability argument subsumes the argument from economics.

11 Coase, The Federal Communications Commission, 2 J. LAw \& Economics 1, 19 (1959) (advocating an auction of radio and television frequencies by the Government to the highest bidder).

12 The validity of the economic argument is limited to cases of share "control," as defined in text accompanying notes $103-13$ infra. The economic rationale could otherwise justify retention of a large premium for even infinitesimally small blocks of stock sold by directors. In those cases the risk that the purchaser is actuated by improper motives is disproportionately large. 
is paying the right amount to the wrong person, ${ }^{13}$ and that all shareholders are entitled to the premium.

Applying the hypothesis of the market, it can be seen that rather than being a depressant on the rights of remaining shareholders, sales of corporate control at a premium will presumably benefit the remaining shareholders. ${ }^{14}$ This is not to say, however, that a rejection of the alternatives posited by Professors Berle and Jennings necessitates a complete absence of liability. Prevention of the economic dislocations resulting from a broad rule of liability does not of itself require exculpating sellers in circumstances where there is actual harm to remaining shareholders. This comment will be concerned with development of a rationale for the imposition of liability and with the measure of damages in cases both of sales of corporate control and recapitalizations. ${ }^{15}$

\section{SALES OF Control}

The courts have thus far uniformly rejected any rule that would impose liability for the premium on the seller in all cases. ${ }^{16}$ Until 1962, however, a rationale was noticeably lacking. In that year the Second Circuit decided Essex Universal Corp. v. Yates, ${ }^{17}$ which served to synthesize the divergent theories of liability.

Essex was an action against the president and chairman of the board of Republic Pictures Corporation, for damages for his refusal to carry out an agreement to sell to the plaintiff 28.3 per cent of the common stock outstanding. The contract price of eight dollars per share was roughly two dollars above quotations on the New York Stock Exchange at the date

13 Bayne, A Philosophy of Corporate Control, 112 U. PA. L. Rev. 22, 64-65 (1963). 14 See generally Hill, supra note 9, for a compendium and exegesis of the possibilities of benefit.

15 It might be argued that the best solution to the problem of purchasers actuated by improper motives is not the imposition of liability on the seller, but rather, the possibility of more careful judicial attention to the abuses of the purchasers. To the extent that judicial scrutiny of day-to-day management can only be cursory, this solution is impractical. See text accompanying notes $80,118-19$ infra.

16 See, e.g., Perlman v. Feldmann, 219 F.2d 173, 178 (2d Cir.) (dictum), cert. denied, 349 U.S. 952 (1955); Levy v. American Beverage Corp., 265 App. Div. 208, 218, 38 N.Y.S.2d 517, 523 (1942); Schwamm v. Alpert, 31 Misc. 2d 768, 769, 221 N.Y.S.2d 917, 919 (Sup. Ct. 1961) ("The mere sale of a controlling stock interest by those who own same gives rise to no duty upon the majority to secure a sale at the same price for all, even though the sellers hold a managerial office in the corporation. . . ."); cf. Honigman v. Green Giant Co., 309 F.2d 667, 670 (8th Cir. 1962) (recapitalization); Manacher v. Reynolds, 165 A.2d 741, 751 (Del. Ch. 1960). But see Sobieski, Securities Regulation in California: Recent Developments, 11 U.C.L.A.L. REv. 1, 19 (1963) (relating California Corporation Commissioners' requirement of an equal offer to all shareholders by the purchaser of a controlling interest).

> 17305 F.2d 572 (2d Cir. 1962), noted in 4 Boston Colleger Industrial \& Commercial L. REv. 421 (1963); 76 HARv. L. REv. 834 (1963); 37 N.Y.U.L. REv. 933 (1963). 
of the contract. The plaintiff contended that the value of the shares on the date set for closing was in excess of $\$ 12.75$ each. Yates, the defendant, moved for summary judgment on the ground that the contract was in contravention of public policy and unenforceable by either party because it provided for immediate transfer of control of the board of directors by the process of seriatim resignations. ${ }^{18}$ Stating that "directorships are fiduciary positions and are not subject to barter and sale,"19 the trial judge granted the defendant's motion.

The Second Circuit reversed on the ground that a provision for seriatim resignation did not make the contract illegal per se under New York law. Of greater significance to sellers of corporate control was the proposed doctrine of liability for the premium enunciated by Chief Judge Lumbard.

A fair generalization from these cases [Gerdes $v$. Reynolds, ${ }^{20}$ Porter v. Healy, ${ }^{21}$ and Perlman v. Feldmann $\left.{ }^{22}\right]$ may be that a holder of corporate control will not, as a fiduciary, be permitted to profit from facilitating actions on the part of the purchasers of control which are detrimental to the interests of the corporation or the remaining shareholders. There is, however, no suggestion that the transfer of control over Republic to Essex carried any such threat to the interests of the corporation or its other shareholders. ${ }^{23}$

The text of Essex thus revolved about the foreseeability of detriment to

18 See text accompanying notes 90-113 infra. Actually the contract only gave the purchaser an option to demand seriatim resignations, but the option had been exercised. Joint Appendix, p. 4a, Essex Universal Corp. v. Yates, 305 F.2d 572 (2d Cir. 1962). The existence of an option was not important on appeal because the court held that it was not severable from the balance of the contract. 305 F.2d at 574-75 (Lumbard, C.J.).

19 Opinion of Dimock, J., Joint Appendix, pp. 3a, 6a, Essex Universal Corp. v. Yates, 305 F.2d 572 (2d Cir. 1962) ("The rule has repeatedly been applied to contracts like the present one ...."). See also text accompanying notes 90-113 infra.

2028 N.Y.S.2d 622 (Sup. Ct. 1941).

21244 Pa. 427, 91 Atl. 428 (1914).

22219 F.2d 173 (2d. Cir.), cert. denied, 349 U.S. 952 (1955). Noted in 40 CoRnell L.Q. 786 (1955); 68 HaRv. L. REv. 1274 (1955); 22 U. CHI. L. REv. 895 (1955).

$23305 \mathrm{~F} .2 \mathrm{~d}$ at 576 . The decision does not, however, lend itself to such easy characterization, because each judge wrote a separate opinion. Judge Clark, the author of Perlman, seemingly concurred in the treatment of Perlman by the Chief Judge, id. at $580 \mathrm{n}$. *. Judge Friendly did not discuss the detrimental sales issue.

The synthesis in the Essex opinion is not completely novel. The clearest exponent of a rule of foreseeable detriment was Hill, supra note 9. Other suggestions of such a foundation are found in Jennings, supra note 2, at 31 ("When we compare the underlying bases of the 'rule of office' and 'corporate transaction' cases, we find a single controlling principle, the abuse of power by the possessor of "control." "); 1 Hornstein, Corporation Law \& Practice \$ 366 , at 481 (1959). See also Comment, 22 U. CHI. L. REv. 895, 901-02 (1955). 
the corporation and to remaining shareholders. In articulating definitions, care must be taken to avoid expansive interpretations which are in practical effect rules of absolute liability. ${ }^{24}$ One need only define detriment to be the premium paid for the power wielded on behalf of all shareholders to come full circle to the view of Professor Berle.

\section{A. Detriment and Foreseeability}

The clearest example of detriment is found in the so-called "looting cases," in which the sellers of control have been subjected to liability because they sold to purchasers who looted the corporation, ${ }^{25}$ or used the corporate assets to pay the purchase price. ${ }^{26}$

In Insuranshares Corp. $v$. Northern Fiscal Corp., ${ }^{27}$ an investment company sued the sellers of controlling shares $(27 \%)$ and the former directors to recover damages sustained as a result of subsequent looting by. the purchasers. Most of the assets of the looted company were securities. The court allowed recovery because:

[T] he circumstances were such as to indicate to any reasonable person ... that there was more than a possibility of fraud and consequent injury to the corporation .... That being so, there plainly was a duty upon the sellers to make a genuine effort to obtain and verify such information ... or ... to refrain from making the sale. ${ }^{28}$

24 See especially the discussion of possible interpretations of the Perlman decision at text accompanying notes $32-47$ infra.

25 Gerdes v. Reynolds, 28 N.Y.S.2d 622 (Sup. Ct. 1941); Insuranshares Corp. v. Northem Fiscal Corp., 35 F. Supp. 22 (E.D. Pa. 1940), noted in Note, Duties of Controlling Shareholders in Transferring Their Shares, 54 HARv. L. REv. 648 (1941); Note, Sale of Controlling Minority Interest Under Questionable Circumstances, 8 U. CHI. L. REv. 335 (1941); cf. Bosworth v. Allen, 168 N.Y. 157, 61 N.E. 163 (1901). But cf. Francis v. Medill, 16 Del. Ch. 129, 141 Atl. 697 (1928).

26 Dale v. Temple Co., 186 Tenn. 69, 208 S.W.2d 344 (1948); cf. Field v. Western Life Indem. Co., 166 Fed. 607 (C.G.N.D. Ill. 1908), aff'd sub nom. Moulton v. Field, 179 Fed. 673 (7th Cir. 1910).

2735 F. Supp. 22 (E.D. Pa. 1940).

$28 \mathrm{Id}$. at 27. (Emphasis added.) This reasoning has been criticized for imposing a broad duty of investigation unsupported by the case law. Note, 40 CoRNELL L.Q. 786, 793 (1955). Such a duty under circumstances indicating a possibility of looting does, however, comport with rough notions of fair play. Note, 54 HARv. L. REv. 648, 654 (1941); Note, 8 U. CHI. L. REv. 335, 337 (1941) (implying a positive duty to investigate the character and finances of the purchaser in all circumstances).

Another investment company case imposed not only liability for the premium, as in Insuranshares, but also for the damages sustained by the corporation. Gerdes v. Reynolds, 28 N.Y.S.2d 622 (Sup. Ct. 1941); see text accompanying note 70 infra, on the issue of damages. Although the opinion has been criticized as unclear, Leech, supra note 2 , at 786-89, the court did formulate a test of "risk reasonably to be perceived." 28 N.Y.S.2d at 653. 
That looting of all the assets of the corporation is detrimental to the other shareholders is obvious; the sole issue in looting cases is foreseeability. ${ }^{29}$

However, in the great majority of cases the detriment is not so clear, and until Essex, there was no clearly articulated basis for liability. Perlman $v$. Feldmann, ${ }^{30}$ the most controversial of the cases imposing liability, was a derivative suit by a remaining shareholder to recover from the selling shareholder the premium he received for selling his thirty-seven per cent controlling interest in Newport Steel Company. ${ }^{31}$ At the time of the sale, steel was in short supply due to the exigencies of the Korean War. Although steel companies generally considered it improper to raise their prices, Newport did in effect raise its prices by demanding interest-free loans from steel consumers. The defendant sold his controlling interest and transferred control of the board to the Wilport Company by the process of seriatim resignation. Wilport was owned by sixteen end-users of steel whose dominant motive, as the trial court found, was to obtain a continuing source of steel supply. The trial court denied recovery, holding that the power to control distribution of the corporate product was "not a corporate asset but rather an attribute inseparably attaching to the stock which, if it has any effect on value, is an inseparable factor entering into the value of the control block." 32 It was found that the value of the controlling shares was twenty dollars each, and that the evidence did not show what the value of the stock would be if shorn of its power to control..$^{33}$ Whether Newport could have,

29 For a collection of facts deemed by the courts to indicate foreseeable detriment in looting situations, see Leech, supra note 2, at 794-96. Some stress has been laid on the fact that liquidity of the corporation's assets is a sine qua non of liability in the looting cases. The distinction does not appear sound, although the courts have imposed liability on the transferor of a non-liquid concern for subsequent looting only once. Dale v. Temple Co., 186 Tenn. 69, 208 S.W.2đ 344 (1948) (oil company); Berle, supra note 2, at 1219. The distinction is only relevant to the ease of calculating actual damages, since the value of liquid assets is by definition readily determinable. The fact that the sale is to a rival of the corporation has not been considered determinative of liability. Stanton v. Schenck, 140 Misc. 621, 251 N.Y. Supp. 221 (1931); cf. Phelan v. Edison Elec. Illum. Co., 24 Misc. 109, 53 N.Y. Supp. 305, (Sup. Ct. 1898). Even so, the court in Stanton looked at subsequent events to negate any inferences of wrongdoing drawn from the fact of sale to a rival, and in Phelan the court marshaled much evidence to rebut wrongdoing.

30219 F.2d 173 (2d Cir.), cert. denied, 349 U.S. 952 (1955).

31 A prior suit relied only on Rule $10(\mathrm{~b})(5), 17$ C.F.R. $\S 240.10 \mathrm{~b}-5$ (1949). The complaint was dismissed on the ground that the rule permits recovery only by persons who have sold or purchased the stock themselves. Birnbaum v. Newport Steel Corp., 193 F.2d 461 (2d Cir. 1952) (A. Hand, J.); 3 Loss, Securtries Regulation 1469 (1961) ("basically correct.").

32 Perlman v. Feldmann, 129 F. Supp. 162, 182 (D. Conn. 1952).

33 Id. at 179. 
at the time of the sale, profitably engaged in borrowing from consumers to further expand and integrate its facilities was not shown, the court said, and implied that in any case, such a transaction might have been unethical in the gray market that existed. ${ }^{34}$

The Second Circuit reversed, assimilating the conduct of the defendant to the appropriation of a corporate opportunity, ${ }^{35}$ because the defendant had failed to "negate completely any possibility of gain by Newport" 36 from interest-free loans tied to sales. It remanded the case to determine the value of the defendant's stock shorn of power to control the output, stating that the burden of proof on that issue also rested on the defendant. ${ }^{37}$

The opinion may be read to betoken liability of the seller for the premium in all cases. The court stated that a mere possibility of detriment suffices to impose liability on the seller, ${ }^{38}$ and imposed the burden on the defendant-seller to negate completely any possibility of detriment. Such a burden of proof would seem to be insurmountable for the seller.

From the fact situation, however, it is clear that a reasonable probability existed that the purchaser of control would sell the corporate product at a lower price to itself than to outside purchasers, i.e., without the necessity of making interest-free loans. The trial court found that Wilport's motive in purchasing control was to acquire a continuing source of steel, which would seem to exclude the possibility that the purchase of control was effected simply as a good investment. Save for economies resulting from vertical integration which were neither alleged nor shown, the purchase of Newport would have resulted in no special advantages to Wilport without wrongful self-dealing. Wilport could have simply bought all the steel it needed at the market price. But if the market was irrational, i.e., steel producers, because of the war effort, charged prices less than those which would result in a maximization of their profits, Wilport may not have gotten an adequate supply by offering the price charged. The irrational market has been offered as one explanation of the premium..$^{39}$ If the decision of the Circuit Court was based on a presumption of an irrational market, the sale of control to Wilport would not have entailed any harm to Newport. It would have received

34 Id. at 175.

35 Judge Swan, in dissent, thought that the majority had adopted the plaintiff's theory that "control of product" was a corporate asset. 219 F.2d at 179.

36219 F.2d at 177.

$37 \mathrm{Id}$. at 178. The court sanctioned recovery by the shareholders directly, thus removing the obstacle of unjust enrichment of the purchaser.

38 Id. at 176-77.

39 Manning, The Shareholder's Appraisal Remedy: An Essay for Frank Coker, 72 YALE L.J. 223, 225 (1962). 
the same price from Wilport that it would have received from any other buyer. The crucial question then in Perlman is whether the free market operated in the steel industry to properly allocate available supply. It is difficult to presume such irrational conduct of steel producers. In fact, the trial court found that Newport's method of raising prices by tying sales to interest-free loans had been to some extent adopted by other steel companies, ${ }^{40}$ an indication of the proper functioning of the market. Furthermore, prices could have been raised indirectly by curtailment of services or a reduction in quality, avoiding charges of wartime profiteering, yet leaving "prices charged" constant. ${ }^{41}$

The interpretation of unfair dealing finds adequate support in the language of the court in Perlman. By assimilating the sale of control at a premium to the appropriation of a corporate opportunity the court implied that the risk that the purchaser would cause the corporation to engage in dealings less favorable than those at arms length was substantial.42 Furthermore, the court stated:

We do not mean to suggest that a majority shareholder cannot dispose of his controlling block without having to account to his corporation for the profits or even never do this with impunity when the buyer is an interested customer, actual or potential, for the corporation's product. But when the sale necessarily results in a sacrifice of this element of corporate good will and consequent unusual profit to the fiduciary who caused the sacrifice, he should account for the gains.43

Thus it is clear that the Second Circuit saw a risk of economic harm to the corporation that was both foreseeable and substantial-the proper touchstone of liability. 44

In Essex, Chief Judge Lumbard not only arrayed Perlman with the looting cases, ${ }^{45}$ but he also characterized the actions of the defendant

40129 F. Supp. at $169,175$.

41 Even if the decision of the Second Circuit in Perlman was properly bottomed on the existence of a reasonable foreseeability of detriment to remaining shareholders, the result is still erroneous because of an absence of actual damages. See text accompanying note 83 infra.

42219 F.2d at $176-77$.

43 Id. at 178. (Emphasis added.) See Note, The Sale of Corporate Control: The Berle Theory and the Law, 25 U. PrrT. L. Rev. 59, 69 (1963), which properly implies that had the buyer been a producer of steel, rather than an end-user, the result would be different because of the absence of foreseeable detriment.

44 Hill, supra note 9, at 990; Katz, supra note 9, at 378, 380; Note, 40 Cornell L.Q. 786, 794 (1955); Comment, 22 U. CHI. L. REV. 895, 900-01 (1955); cf. Honigman v. Green Giant Co., 309 F.2d 667, 670 (8th Cir. 1962); Manacher v. Reynolds, 165 A.2d 741 (Del. Ch. 1960). But see Benson v. Braun, 141 N.Y.S.2d 286, 289 (Sup. Ct. 1955) (semble), aff'd mem., 286 App. Div. 1098, 145 N.X.S.2d 711 (1955).

45305 F.2d at 576. See Note, The Sale of Corporate Control: The Berle Theory and 
Feldmann as the appropriation of a "corporate asset." 46 The language is indicative of more than a mere possibility of detriment. He stated that the rule of the arrayed cases was that a controlling shareholder is liable for facilitating detriment to the remaining shareholders ${ }^{47}$-a rule inconsistent with the irrational market theory in Perlman. In the irrational market situation Wilport would pay the same price as other endusers of steel and no detriment would have resulted to Newport.

A further problem is the possibility of detriment where the purchaser of control has first made an offer to purchase all or substantially all the assets or outstanding shares of the corporation, but later purchases only the controlling shares at a premium.

In Commonwealth Title Insurance \& Trust Company v. Seltzer, ${ }^{48}$ a corporation had its "whole capital" invested in a single parcel of realty, which the purchaser wished to acquire. An agent of the purchaser approached one defendant, a director, with an offer to purchase the realty. This offer was rejected and the transaction was consummated by the purchase of the controlling shares from the defendants. The real estate was then sold to the purchaser by the corporation at a "price not found to be inadequate." 49 The court required the defendants to pay to the corporation the profits realized in purchasing stock to gain control and then selling it. It characterized what transpired as a corporate transaction. ${ }^{50}$ Although the case may be interpreted as one bottomed on a theory of possible misrepresentation to the shareholders who sold to the defendants, ${ }^{51}$ (in that recovery was measured by the profits made in deal-

the Law, 25 U. PrrT. L. REv. 59, 69 (1963), which disputes the contention of Professor Hill that Perlman was a logical extension of the looting cases. The author there would characterize Perlman as the "wrongful appropriation of a corporate asset by the seller." If the distinction is based on the supposition that only the seller is involved in wrongdoing in Perlman, whereas in the looting cases the buyer is the wrongdoer, he is rebutted by the implications from his hypothetical case based on Perlman, in which the buyer was a producer rather than an end-user of steel. See note 43 supra.

46305 F.2d at 576 .

47 See text at note 23 supra.

48227 Pa. 410, 76 Atl. 77 (1910).

49 Id. at 415,76 Atl. at 78 .

50 "[T] $]$ here is little or no doubt that the profits paid to the two defendants were ... part of the cost of the real estate. . . The defendants knew this, and the facts justify the inference that the stock dealing was for the very purpose of diverting a part of the price from the corporation into their own pockets ..." Id. at 417,76 Atl. at 79.

But cf. Abelow v. Symonds, 184 A.2d 173 (Del. Ch. 1962). There plaintiff was a minority shareholder of a subsidiary which sold its assets to the defendant parent corporation. In response to the plaintiff's contention that he would have received more by a merger or sale to a third party, the court denied relief, because an adequate price had been received. $I d$. at 175,176 .

5 In two related cases, Seltzer and the corporate transaction doctrine were relied 
ing with the shares obtained from those shareholders) the result is more consonant with an interpretation of liability for the premium. First, recovery was had by the corporation rather than by the misled selling shareholders. ${ }^{52}$ Second, the defendant's profits resulted from amassing control-no misrepresentation was shown. ${ }^{33}$

Another case, Tryon v. Smith, 54 was an action by former minority shareholders of a bank to recover their aliquot portion of the premium received by the defendant from the sale of his seventy per cent interest to Transamerica Corporation at $\$ 460.00$ per share. Transamerica had earlier approached the defendant, the president and a director of the bank, with an offer to purchase all of the outstanding stock. He refused,

upon to avoid a decision on the question of whether an officer or director owed the shareholders who sold to him a responsibility of disclosure. Roby v. Dunnett, 88 F.2d 68 (10th Cir. 1937); Dunnett v. Arn, 71 F.2d 912 (10th Cir. 1934).

52 "Although the proceeding was in form derivative, since the corpowation had distributed most of its assets and appatently had only a formal existence, the court gave a personal recovery rather than indulging in the more expensive remedy of appointing a receiver." Jennings, Trading in Corporate Control, 44 CAlIf. L. REv. 1, 23 (1956). Professor Jennings views this relief as the precursor of the individual recovery which was granted in Perlman to avoid the problem of unjust enrichment of the purchaser. 219 F.2d at 178.

53 While it is true that the defendant-directors in Seltzer did not resign in favor of the purchaser, this fact should be inconsequential to the result. Professor Leech suggests that the court might have had trouble with the. problem of establishing a fiduciary duty had the defendants resigned, and points to the fact that the lower court was unsure of what would happen in such a situation. Leech, Transactions in Corporate Control, 104 U. PA. L. REv. 725, 778 \& n.147 (1956).

In a similar case, Keely v. Black, 91 N.J. Eq. 520, 111 Atl. 22 (Ct. Err. \& App. 1920), the purchaser of controlling shares sought to acquire an asset of the corporation, namely a contract to furnish telephone service to an army base. Defendant, the president, held $25 \%$ of the stock. The defendant acquired an additional $70 \%$ of the outstanding stock, and then sold the $95 \%$ to the purchaser at a premium. In a derivative suit, the court denied recovery to the plaintiff, a remaining shareholder, because the money was paid to defendant "for his services in acquiring and transferring the stock, and in doing that he did not occupy a position of trust with relation to the company of which he was president." Id. at 523, 111 Atl. at 23. The court was doubtless motivated by the presumption that corporate recovery was necessary, and that thereby the purchaser would receive 19/20 of the damages. Stanton v. Schenck, 140 Misc. 621, 642, 251 N.Y. Supp. 221, 239-40 (Sup. Ct. 1931) (citing Keely). Other courts have also taken the position that establishment of a fiduciary relation depends upon the capacity in which defendant acted. Levy v. American Beverage Corp., 265 App. Div, 208, 216, 38 N.Y.S.2d 517, 525 (1942); Benson v. Braun, 141 N.Y.S.2d 286, 288 (Sup. Ct.), aff'd mem., 286 App. Div. 1098, 145 N.X.S.2d 711 (1955).

Perhaps the short answer to this problem is that "the contention that a controlling shareholder is entitled to sell his shares for anything he can get-provided only that he himself has studiously avoided becoming a director or officer-cannot commend itself to any system of justice." 1 Hornstein, op. cit. supra note 9 , at 481 ; cf. 305 F.2d at $575 \mathrm{n} .3$. Nor can the distinction based on the capacity in which the defendant acted so commend itself. See Leech, supra at 776 \& n.140.

54191 Ore. 172, 229 P.2d 251 (1951). 
telling Transamerica that it should deal directly with minority shareholders. Transamerica purchased the stock of the minority at $\$ 220.00$ per share, and subsequently concluded the purchase from the defendant. The court sustained the transaction on the ground that no fiduciary relationship of the majority and minority existed, and for that reason the majority had neither a duty to seek equal prices nor to apprise minority shareholders of Transamerica's prior offer. ${ }^{55}$ The principle of Tryon would surely encompass and uphold a transaction in which the purchaser had previously made an offer for all or substantially all the outstanding shares, but instead purchased only the control block at a premium.

To examine the existence of possible detriment in these prior offer cases, assume, first, that the purchaser made a prior offer to the corporation for all the outstanding shares or assets, but bought only controlling shares and that the evidence showed conclusively that the purchaser did not intend to sell the assets to himself, or to buy any more shares. Should the seller be liable for any premium in this situation?

Aside from the argument of Professor Jennings that the sale at a premium would raise a presumption of harm, ${ }^{56}$ which is rebutted by the evidence in the hypothetical case, it is difficult to see any basis for liability. The remaining shareholders could argue that the purchase of control achieved the same result as could have been achieved by a merger or purchase of assets, namely an investment by the purchaser in the business. Either merger or purchase would have resulted in equal treatment for all shareholders. The argument would conclude that the seller, by use of his position, changed the form so as to divert to himself a portion of the recovery that would have inured to all the shareholders. A rule of seller's liability based on the diversion argument is undesirable for two reasons. First, a merger or sale of assets would not have occurred without the payment of the premium price to the seller of control. The seller would not consent to either of these forms unless he received the same price as that at which he sold the controlling shares. And, presumably, the purchaser could not afford to pay the higher price to all the shareholders. Indeed, because sale of assets or merger would be blocked by the higher price the seller required, the remaining shareholders derive a benefit from the sale of the controlling shares resulting from the probability of more efficient management by the purchaser. ${ }^{57}$ Second, there are obvious difficulties in defining the situation in which liability for the premium is to be imposed.

55 Id. at 180, 229 P.2d at 254.

56 Jennings, supra note 52, at 16-19.

57 See text accompanying notes 10-12 supra. 
[W] hen there is a buyer seeking either all of the shares of a "corporate transaction" such as a merger or asset purchase ... the argument for "equality" is at its strongest since equality would be the rule in case of a "corporate transaction." ... But how is one to define the situation in which the restriction is to apply? ... Will the presence of any such proposal ... bring the restraint into operation? Or must it be an offer on terms which are later found to be "adequate?"58

As a second hypothetical, assume that after the prior offer for all the assets or outstanding shares, the purchaser bought only controlling shares at a premium and the evidence showed a substantial risk or a certainty that the purchaser would sell the assets to himself. The argument that the selling controlling shareholder has diverted a portion of the corporation's assets to himself depends on the following reasoning: The prior offer indicates that the purchaser has only a limited amount of capital with which to acquire all the assets. ${ }^{50}$ When he buys controlling shares at a premium he will necessarily have to pay less on a pro rata basis to the remaining shareholders. ${ }^{60}$ The argument assumes, however, that the purchaser's limited amount of capital per share will approximate the market value of non-controlling shares. To base this assumption on the existence of a prior offer of even infinitesimal size appears unrealistic. The transaction can more easily be interpreted as indicating a desire of the purchaser to expedite the purchase of the remaining interests at the same price. This is so because it is more consonant with the existence of a competitive market in share interests in corporations to assume that the value per share of one hundred per cent interests in corporations equals the per share value of controlling interests, than it does noncontrolling interests. It is evident, therefore, that where the purchaser intends to purchase all the assets from the corporation, the existence of the premium and the prior offer in themselves are insufficient to indicate the probability of detriment. Liability of the seller should instead depend on the foreseeability that the purchaser will pay a lower pro rata price to the remaining shareholders on a purchase of the assets.

The existence of the prior offer may be relevant where the purchaser's plans to acquire control of all the assets do not appear. It may be argued that the prior offer itself indicates a substantial risk of a purchase of

58 Katz, supra note 9 , at 380,385 .

59 See text accompanying note 57 supra.

60 Cf. Porter v. Healy, 244 Pa. 427, 91 Atl. 428 (1914), where the purchaser bought all the outstanding shares in one transaction for an equal price, and then paid an additional $\$ 115,000$ to the defendants on passage of control of the board by a seriatim resignation. The court predicated liability on the theory of sale of office. Id. at 437, 91 Atl. at 431-32. 
all the assets or stock at a price less than that paid the controlling shareholder. But in terms of the foreseeability test of Essex, substantial risk is a question of fact dependent upon other factors, such as whether the purchaser could have used the assets for an already existing business and the ability of the purchaser to pay for later purchase of the assets.

To minimize the possibility that the purchaser will sell the assets to himself or deal unfavorably for the remaining shares, disclosure of the prior offer to all shareholders by those in control is desirable. ${ }^{61}$ It might be argued that disclosure has no effect, whether remaining shareholders wish to sell or not, because the purchaser can always sell the assets to himself at a lower price. Where, however, shareholder approval of the sale of assets is required ${ }^{62}$ and the controlling block does not suffice for such approval, disclosure of the prior offer may cause the remaining shareholders to vote against the sale. Furthermore, disclosure may enlarge the possibilities of litigation about the price received for the sale of assets, and dissuade the purchaser. Disclosure may also serve to forestall acquisition of more shares by the controlling shareholders, as in Seltzer. ${ }^{63}$ The duty to disclose should arise at the date of the offer for assets or all the stock, since the purchaser or controlling shareholder may buy minority shares before the controlling interest is transferred, as in Tryon v. Smith. A California opinion, Low v. Wheeler, 64 imposed a duty to disclose even though the defendant, a controlling shareholder, had not sold his shares to the purchaser until after the plaintiff had sold his. The court, however, in imposing liability for the premium on the defendant, ${ }^{65}$ confined the rule to cases of small numbers of shareholders,

61 Leech, supra note 53 , at 801 .

62 ILL. REv. STAT. ch. 32, $\$ 157.72$ c (1961) (requirement of $2 / 3$ vote); ABA-ALI ModeL Bus. CoRP. ACT \& 72 (1953).

63 If liability is imposed on the selling shareholder to protect against nondisclosure by the purchaser or by the controlling shareholder when buying shares of the minority, to the extent that the premium is recovered by the corporation or remaining shareholders the parties sought to be protected are not compensated. Perhaps if compensation of selling shareholders were the sole reason for disclosure, liability for the premium should not be imposed, and defrauded minority shareholders should be left to their common law and statutory remedies. See generally Comment, Insider Liability Under Securities Exchange Act Rule 10b-5: The Cady, Roberts Doctrine, 30 U. CHI. L. REV. 121 (1962).

6424 Cal. Reptr. 538 (Dist. Ct. App. 1962).

65 See also Mayflower Hotel Stockholders Protective Comm. v. Mayflower Hotel Corp., 173 F.2d 416, 425 (D.C. Cir. 1949), where the court held that an allegation "that the majority stockholders and three key directors wilfully and in pursuance of a conspiracy withheld vitally important information [an offer to purchase the hotel, the major asset of the corporation] from their associates on the Board of Directors and from the stockholders at large" stated a cause of action. It was "information . . to which they were entitled under every rule of law and equity." Ibid. Quaere: Were the shareholders, directors, or both entitled to the information? $C f$. Ingraham v. National 
where the purchaser desires immediate purchase of the minority and where an offer to purchase assets is involved. ${ }^{66}$

But in the area of detrimental sales, protection will be afforded not by disclosure but by liability of the seller in spite of disclosure of offers. The proper test of liability of the selling shareholder is the reasonable foreseeability that the sale will result in economic detriment to the remaining shareholders. ${ }^{67}$

\section{B. Damages}

Contemporary doctrine envisages recovery of the premium by remaining shareholders in cases of detrimental sales of controlling shares. Underlying the choice of the premium as the measure of damages are the complementary goals of deterring the seller's conduct by depriving him of the control premium and of compensating the injured shareholders. The rationale justifying recovery of the premium in order to compensate the injured shareholders assumes that the premium approximates the actual damages. Surely a purchaser who is planning to loot the corporation of all its assets could afford to pay more for controlling shares than the market value of non-controlling shares. But if perfect competition exists in the market for controlling interests, he would be irrational in offering to pay more for a controlling interest than the competitive price for such interests. Should the seller attempt to charge more, the purchaser would simply buy a different controlling interest. If the seller has knowledge that the purchaser is planning to loot the corporation, he will not sell to the looter at the competitive price. Possibilities of liability and the loss of prestige in the business community resulting from sale to a looter result in higher costs in selling to looters. The seller may be able to increase the price by these costs so long as the looting purchaser cannot find sellers who are unaware of his plans. It cannot be supposed that sellers who are unaware of the purchaser's plans would resist selling to him at the competitive price for controlling interests, plus one dollar, because they are unaware of the higher costs. In all probability, then, the price paid by a wrongful purchaser of controlling interests will be equal to the competitive price for such interests. One would expect that

Salt Co., 36 Misc. 646, 647-48, 74 N.Y. Supp. 388 (Sup. Ct. 1902) (moral if not legal duty of officers to disclose offer to purchase majority of stock).

66 Low v. Wheeler, 24 Cal. Reptr. 538, 543 (Dist. Ct. App. 1962): "[I]n general, majority stockholders need not tell minority stockholders of negotiations for sale of stock. . . . Sale of shares would not necessarily produce, as would sale of assets, a pro rata distribution."

67 Hill, The Sale of Controlling Shares, 70 HaRv. L. Rev. 986, 1025 (1957), suggests that the burden of going forward with evidence of foreseeable detriment should be on the remaining shareholders, but that the seller has the burden of persuasion. 
wrongful purchasers would converge on sellers who, because of their negligent lack of investigation of motives, are indifferent to the higher costs in dealing with such purchasers. It is unlikely that the price paid by looting purchasers to unknowing sellers will diverge from the competitive price for controlling interests-because of the convergence of looters on unknowing sellers-and thus approximate the price that would be charged looters by knowing sellers. This result is unlikely because it not only presumes a relatively small number of negligent sellers but also because it presumes that a great percentage of all purchases of controlling interests are wrongful. This latter assumption, though consistent with the views of Professor Jennings, lacks empirical support. Because wrongful purchasers do not constitute an overwhelming portion of the demand for controlling interests, any convergence by them on unknowing sellers tending to raise the price above the competitive price for controlling interests will simply cause purchasers who do not have wrongful motives to buy from non-negligent sellers and drive the price back to the competitive price. In sum, the only justification for imposing liability for the premium is to deter negligent sellers by imposing liability for a figure which is in no way related to the wrongdoing.

The major difficulty with using the premium as the measure of the negligent seller's liability is the lack of relation between the premium and actual damages. Suppose that the seller of control has been negligent, has not received a premium and the purchaser has looted the corporation. Is the seller to be excused from liability because of the absence of a premium? The seller should not be excused, because he was negligent and thereby caused injury to the remaining shareholders. The existence or non-existence of the premium is meaningless. Actual damages were assessed against the seller in the looting cases. ${ }^{68} \mathrm{It}$ is submitted that actual damages are always the appropriate quantum of recovery. ${ }^{69} \mathrm{Im}$ position of actual damages can be expected to act as a deterrent, and also to properly compensate the injured shareholders. The court in Gerdes $v$. Reynolds,70 however, awarded not only actual damages but also the premium received by the seller. Such double recovery would seem improper except as a punitive sanction where the seller's actions are flagrant or fraudulent. ${ }^{71}$

68 Insuranshares Corp. v. Northern Fiscal Corp., 35 F. Supp. 22 (E.D. Pa. 1940). See also Dale v. Thomas H. Temple Co., 186 Tenn. 69, 91, 208 S.W.2d 344, 347 (1948). Plaintiffs frequently request actual damages. Levy v. American Beverage Corp., 265 App. Div. 208, 38 N.Y.S.2d 517 (1942) (illegal profits and losses of the corporation); cf. Bosworth v. Allen, 168 N.Y. 157 (1901) (premium and losses suffered by the corporation).

69 Comment, 22 U. CHr. L. REv. 895, 902 (1955).

7028 N.Y.S.2d 622 (Sup. Ct. 1941); supra note 28.

71 Note, 68 HARV. L. REv. 1274, 1276 (1955). 
As a second example of lack of relation between the premium and actual damages, assume that the seller received a premium in a situation where a substantial risk of foreseeable detriment existed. Also assume that the remaining shareholders bring their derivative suit against the seller before actual damages have occurred, or that the corporation has prospered under the skillful management of the purchaser. In this case, imposition of liability on the seller would strain the foundations of the tort theory on which recovery should be based. Because the standard of liability should be one of negligence, in the absence of actual damages one finds it difficult in the law of torts to find a basis for recovery beyond a nominal amount. ${ }^{22}$ And analysis of the traditional rules of prophylaxis in the law of corporations and trusts does not disclose any situations where liability is imposed by the judiciary in the absence of actual or presumed damages. When a director or officer is held liable for the appropriation of a corporate opportunity, ${ }^{73}$ recovery, measured by the defendant's profits or the value of the asset, is of actual damages. The amount recovered is simply the best measure of the profits the corporation would have made. ${ }^{74}$ Section 16(b) of the Securities Exchange Act of 1934,75 the only prophylactic remedy in corporation law that imposes liability in absence of damages, does so because of a legislative determination that it is impossible to acquire information about the many permutations of insider wrongdoing. Furthermore, it is presumed that of the transactions deterred, a significant proportion arise from the misuse of inside information. ${ }^{76}$ In the law of trusts, when a breach of trust has

72 Gregory \& Kalven, Cases on Torts 23 (1959) ("To be sure, actual damage is a necessary part of a cause of action based on negligence .... '); 2 HARPER \& JAMES, TORTS 1299-1300 (1956) (Damages in Accident Cases): "The cardinal principal of damages . . . is that of compensation for the injury caused to plaintiff by defendant's breach of duty. There are other traditional strains. Where the injury is intended ... punitive damages are sometimes allowed."

73 See, e.g., Irving Trust v. Deutsch, 73 F.2d 121 (2d Cir. 1934) (Swan, J.), cert. denied, 294 U.S. 708 (1935); Guth v. Loft, Inc., 23 Del. Ch. 255, 5 A.2d 503 (Sup. Ct. 1939).

74 But cf. Wooten v. Wooten, 159 F.2d 567 (10th Cir.), cert. denied, 331 U.S. 835 (1947). The court in Wooten imposed liability on a trustee who had appropriated a "trust opportunity," rejecting a defense that the same investment by the trust would have been improper. See also Kaplan, Conflict of Interest in Corporations, ConfERENce oN Conflict of INTEREST 34, 42-43 (U. Chi. Law School Conference Series No. 17, 1961), which raises the possibility of multiple liability of an officer or director of several corporations who has appropriated an opportunity which each could have claimed. If multiple liability for profits is imposed, any resemblance to actual damages suffered is minimal.

7548 Stat. 896 (1934), 15 U.S.C. § 78p (1958).

70 Kaplan, Wolf v. Weinstein: Another Chapter on Insider Trading, 1963 Sup. CT. REv. 273, 301. Section 16(b) awards recovery to the corporation of short-swing profits of insiders. It does not compensate those who are presumably injured in their share transactions with insiders. See Conant, Duties of Disclosure of Corporate Insiders Who 
occurred, the remedy of a beneficiary to recover the profits of the trustee resulting from the breach ${ }^{77}$ is properly viewed as the best measure of the profits that would have accrued to the trust estate in the absence of breach.

It may be argued that, nevertheless, liability should be imposed on the seller in the absence of actual damages for the following reasons: First, an injunction will normally not be available because the sale will already have been consummated. ${ }^{78}$ Even if available, it will probably be denied because of the speculative nature of the injuries.79 Second, the seller should not be excused, because it is probable that the detriment will arise, or has already occurred, in subtle form, such as overpayment of salaries. Thus the existence of actual damages should be presumed because of the inadequacy of judicial scrutiny of officer's salaries. ${ }^{80}$ This basis for imposing liability in the absence of actual damages, while it properly indicates the inadequacies of present corporation law, is undesirable. As has been shown, the premium bears no relation to the amount of actual damages, and unlike the defendant's profits in cases of the appropriation of a corporate opportunity or a breach of trust, ${ }^{81}$ the presumption of equivalence cannot be indulged. The proper solution is closer judicial attention to the question of actual damages. ${ }^{82}$

In light of the propriety of a requirement of actual damages, the decision in Perlman v. Feldmann must surely fall. The plaintiff's theory

Purchase Shares, 46 CoRnerl L.Q. 53, 64 (1960) ("One must conclude that the corporate title to the special knowledge within the firm and the basic trust relations of insiders to their firm create fiduciary duties to the corporation in this situation, not to the selling shareholders.").

772 ScotT, Trusts § 205 (1956); cf. Donemar, Inc. v. Molloy, 252 N.Y. 360, 169 N.E. 610 (1930) (recovery of employee's profits from a breach of duty of loyalty).

78 But see text accompanying notes 65-67 supra.

79 Schwamm v. Alpert, 31 Misc. 2d 768, 221 N.Y.S.2d 917 (Sup. Ct. 1961); Francis v. Medill, 16 Del. Ch. 129, 141 Atl. 697 (1928); Phelan v. Edison Elec. Illum. Co., 24 Misc. 109, 53 N.Y. Supp. 305 (Sup. Ct. 1898); cf. Ingraham v. National Salt Co., 36 Misc. 646, 74 N.Y. Supp. 388 (Sup. Ct. 1902).

80 See, e.g., Rogers v. Guaranty Trust Co., 288 U.S. 123 (1933); Rogers v. Hill, 289 U.S. 582 (1933); text accompanying notes 119 infra.

81 In Insuranshares Corp. v. Northern Fiscal Corp., 35 F. Supp. 22 (E.D. Pa. 1940), the court found reasonable foreseeability of detriment in a looting case and there was no premium paid to the seller of control.

82 Gf. Patton v. Nicholas, 154 Tex. 385, 279 S.W.2d 848 (1955). Patton was a suit by a minority shareholder for liquidation on the ground of malicious suppression of dividends. The Texas Supreme Court denied liquidation, and required a decree on remand providing for a reasonable dividend at the earliest practical date plus retention of jurisdiction over the corporation by the court for the protection of the plaintiff. Id. at 398-99, 279 S.W.2d at 858. A retention of jurisdiction over the corporation when a reasonable possibility of detriment has been shown but damages have not yet occurred is an interesting possibility. 
did not stand on proof of actual damages and the trial court made a specific finding that no actual damages to the corporation had resulted from the control of the purchaser. 83

The second major difficulty in the area of damages is the possibility of double recovery. ${ }^{84}$ Suppose that the corporation or the remaining shareholders in a looting case, after recovering actual damages from the seller, sue the looters. Can the looters successfully plead satisfaction? The possibility of unjustly enriching the shareholders is obvious whether recovery from the seller is by the corporation, or, as in Perlman, by the remaining shareholders directly. Direct recovery was allowed in Perlman to avoid unjustly enriching the purchaser. ${ }^{85}$

The proper solution is to allow a suit by the seller to recover his entire liability from the purchaser, who is after all more culpable. This rule of indemnity would comport with the modern law of contribution applicable to joint tortfeasors and co-trustees.86 Full compensation for the injured shareholders will result, without the undesirable effects of double recovery or of freeing the wrongdoing purchaser from liability. It cannot be contended that the seller will be unjustly enriched by his indemnity for actual damages. ${ }^{87}$ For although after indemnity of actual damages he will have retained all the benefits of a sale at a premium,

83 "Since the Wilport nominees took over . . . substantial improvements have been made in Newport's property and the corporation has enjoyed continued prosperity. Although the Wilport stockholders have purchased substantial quantities of steel from Newport, no sales were made at less than Newport's quoted mill prices. There is no evidence of any sort that Newport has suffered from mismanagement or inefficient management . . or that it has suffered or is likely hereafter to suffer any harm whatever at the hands of its new management, or that its new management has in any way failed to do anything which should have been done for the good of the corporation." 129 F. Supp. at 175-76.

84 Cf. Francis v. Medill, 16 Del. Ch. 129, 133-34, 141 Atl. 697, 699 (1928) (recovery can always be had from the purchaser).

85 Allowing recovery directly to the remaining shareholders to avoid unjustly enriching the purchaser is eminently proper. Where the corporation has been completely looted of its assets, corporate recovery should be granted to the extent necessary for the protection of corporate creditors. Note, Disregard of the Corporate Entity for the Benefit of Shareholders, 1963 Duke L.J. 722, 728-30. See also Note, Shareholders' Right to Direct Recovery in Derivative Suits, 17 WYo. L.J. 208 (1963).

86 I HARPER \& JAMES, TORTS § 102 (1956); 3 ScOTT, TRUSTS § 258 (1956): "Ordinarily anyone of the trustees who makes good the breach of trust is entitled to contribution from the other trustees .... There are, however, three limitations on the rule as to contribution: (1) where one of the trustees is substantially more at fault than the others; (2) where one of the trustees profits from the breach of trust; (3) where the breach of trust is committed in bad faith." Because the premium is not attributable to the wrongdoing of the purchaser, the seller cannot be considered to have profited from the transaction. Thus, he should not be denied recovery by the second exception to contribution stated by Scott.

87 See text at Part B supra. 
the sale price was in no way inflated by the risk of wrongdoing. The seller received no more than the competitive price for corporate controlling shares. The only objection that can be made to a rule of indemnity in favor of the negligent seller of controlling shares is that he will not be deterred from making the sale. The possibility of indemnity, it is submitted, would do little to minimize the deterrent effect of the risk of seller's liability. Where looting is foreseeable, no reasonable seller would expect to be able to subsequently locate the looter. And if indemnity is allowed to the seller where the actual damages are the entire value of the corporation, it would be an anomaly to deny indemnity in cases of less detriment.

The seller should therefore be liable only for actual damages attributable to the foreseeable conduct of the purchaser and should be allowed complete indemnity from the purchaser for his liability.88 Recovery of actual damages by the remaining shareholders from the seller should bar any action by the remaining shareholders against the purchaser, in order to obviate double recovery. 89

\section{Seriatim Resignations}

Although the prior New York case law had held that a bargained-for acceleration of board control was improper and "incidental" transfer of

88 Although the instances in which courts have imposed liability for the premium on wrongdoing sellers are not many, it is perhaps too much to expect that at this date the courts will depart from the assumption of most commentators that it is the appropriate remedy. Calculation of the premium may be a difficult undertaking. The premium is properly defined as price paid for controlling shares less investment value. Leach, Transactions in Corporate Control, 104 U. PA. L. REv. 725, at 818 (1956). The Second Circuit in Perlman stated that damages were to be the sales price for the controlling shares less the value of the appurtenant power to control the corporate product. 219 F.2d at 178. This approach, implying that the price paid varies with the amount of detriment, should be rejected. Normally, investment value is equal to market value on an exchange. But where market value is unrealistic because of management dealings, as in the Perlman remand, the investment value of the seller's stock may be determined by its pro rata share of enterprise value. Perlman v. Feldmann, 154 F. Supp. 436, 451 (D. Conn. 1957); Bonbright, The Valuation of Property (1937), quoted in Blum, Materials on Insolvency and Reorganization 231-32 (1960). See also Eastern Gas \& Fuel Associates, 30 S.E.C. 834 (1950).

In the Perlman remand, the court committed itself to the use of enterprise value at the date of the sale, yet allowed the parties at their urging to introduce evidence of events subsequent to the date of sale on the issue of value. 154 F. Supp. at 447-48. This result involves double counting. If the foreseen detriment has materialized, it may have reduced enterprise value below that at the date of the sale.

If the seller were liable in every case for the premium, the seller could properly contend that in the absence of a market value he had no guidance as to the proper sales price and that therefore he should not be liable for a premium calculated by the enterprise value technique.

89 Prosser, Joint Torts and Several Liability, 25 CALIF. L. REv. 413, 421-22 (1937). 
board control was legal,90 Essex rejected this distinction and held that, absent a showing of probable detriment to the corporation, a clause providing for seriatim resignations in a contract to sell working share control was not per se illegal.91

The doctrine that bargained-for transfers of control of management are illegal proceeds from the notion that control is a corporate asset-a power to be used for the benefit of all shareholders. ${ }^{22}$ The reasoning is that those in control should not limit their discretion or exercise it for their own benefit. Analogies are abundant. Contracts to cause directors to resign are illegal, ${ }^{93}$ as are contracts among shareholder-directors to choose and perpetuate management, ${ }^{94}$ and contracts to sterilize the board.95 Similarly, a trustee may not receive payment for surrender of his position to another. ${ }^{96}$ This rule has been properly applied in cases of mutual insurance company officials selling their offices.97 A final analogy is to the corporate electoral process, where, because of principles of corporate democracy, the shareholder cannot sell his vote..$^{88}$

90 Benson v. Braun, 8 Misc. 2d 67, 71, 155 N.Y.S.2d 622, 624 (Sup. Ct. 1956); San Remo Copper Mining Co. v. Moneuse, 149 App. Div. 26, 28 (1912).

91 "A matter so practically important as achieving immediate rather than deferred acquisition of control over the day-to-day operations of the corporation in which Essex was making such a substantial investment cannot be dismissed as a mere 'incidental provision.'" 305 F.2d at 574.

92 Berle, "Control" in Corporate Law, 58 Colum. L. REv. 1212, 1217, 1219 (1958).

93 Forbes v. McDonald, 54 Cal. 98 (1880), involved the illegality of a contract between a director, who held the deciding vote in an equal split between two factions, and one of the factions. The director agreed to resign and aid that faction in electing a successor of its choosing.

94 McQuade v. Stoneham, 263 N.Y. 323, 189 N.E. 234 (1934); Van Slyke v. Andrews, 146 Minn. 316, 178 N.W. 959 (1920). McQuade was overruled by N.Y. Bus. CoRP. LAw $\S 620(\mathrm{~b})(1961)$, which allows limitations on the discretion of management, providing all incorporators agree.

95 Manson v. Curtis, 223 N.Y. 313,119 N.E. 559 (1918). The result in Manson has been overruled by statute. See note 94 supra.

96 Sugden v. Grossland, 3 Sm. \& Giff. 192, 65 Eng. Rep. 620 (Ch. 1856); cf. RestateMENT, TRUSTs $\S \S 106,203,205$ (1935) (resignation and liability of trustee); 2 Scotr, Trusts $\$ 171.1$ (1956) (liability for delegation of entire administration).

o7 Field v. Western Life Indemnity Co., 166 Fed. 607 (N.D. Ill. 1908), aff'd sub nom. Moulton v. Field, 179 Fed. 673 (7th Cir. 1910); McClure v. Law, 161 N.Y. 78, 55 N.E. 388 (1899) (probably a mutual company-no share transfers involved in the case); cf. Heineman v. Marshall, 117 Mo. App. 546, 92 S.W. 1131 (1905). An English case standing for the same proposition served as the precursor of statutes which prohibit payments made to directors as compensation for loss of office or in connection with retirement unless disclosed to and ratified by the shareholders at a general meeting. Gaskell v. Chambers, 26 Beav. 360, 53 Eng. Rep. 937 (Ch. 1858); Companies Act of 1948, 11 \& 12.Geo. VI, c. 38, \$\$ 192-94; GoWer, The PrINCIPLes of MODERN CoMPanY LAw 489-92 (2d ed. 1957).

98 See and compare 1 Hornstein, Corporation LAw and Practice, 212 (illegal sales of votes by shareholders). 
In spite of the persuasiveness of these arguments, they are inapposite when share control is transferred. When the seller ceases to have control of the corporation it is preferable that he and his representatives resign from the board and be replaced by the purchaser, who does have a monetary stake. ${ }^{99}$ Further, if the purchaser acquires controlling stock, there is nothing to prevent him from electing his own board at the next election. ${ }^{100}$ These factors, in addition to the economic argument that purchasers might be discouraged if they had to assume the risk of mismanagement at the hands of the seller and his representatives ${ }^{101}$ after the sale, are decisive in favor of permitting transfer of a board by seriatim resignation to the purchaser. ${ }^{102}$

The proper rule would be to allow a provision for seriatim resignations in a contract for a sale of controlling shares. ${ }^{103}$ If, however, the

99 Barnes v. Brown, 80 N.Y. 527, 537 (1880).

100305 F.2d at 575. A complication with this assertion is suggested by the facts of Essex, where the by-laws of the corporation provided for staggered election of the board of directors. It can be contended that statutes permitting the staggering of elections of board members reflect approbation of continuity of management and disfavor of too rapid change, and that therefore the manner of change provided for in the by-laws should be respected. Compare Investment Co. Act of 1940, 54 Stat. 813 (1940), I5 U.S.C. $\$ 80 \mathrm{a}(16)$ (a) (1958) (limiting seriatim resignation in investment companies to one-third of the board). The failure of the court in Essex to discuss this issue may stem from a general view that the purpose of staggering is to circumvent the requirement of cumulative voting. See, e.g., Wolfson v. Avery, 6 Ill. 2d 78, 126 N.E.2d 701 (1955); Janney v. Philadelphia Transp. Co., 387 Pa. 282, 128 A.2d 76 (1956). To disallow seriatim resignation where the by-laws provide for staggering would serve to further discourage sales of control, in that the risks attendant on purchase by allowing the seller to control would be greatly magnified.

101 Essex Universal Corp. v. Yates, 305 F.2d 572, 578 (2d Cir. 1962).

102 Comment, 37 N.Y.U.L. Rev. 933 (1962). But see Note, 4 Boston College Industrial \& Commercial L. REv. 421, $422-25$ (1962); Note, 40 CoRNeIx L.Q. 786, 789-91 (1955). See also Hill, The Sale of Controlling Shares, 70 HARv. L. REv. 986, at 994, 1006 (1957); Leech, Transactions in Corporate Control, 104 U. PA. L. REv. 725, 807-08 (1956), to the effect that a clause for seriatim resignation is generally irrelevant on the issue of whether a reasonable foreseeability of detriment existed.

103 Cf. SEC v. Insurance Sec., Inc., 254 F.2d 642 (9th Cir. 1958). But cf. Krieger v. Anderson, 173 A.2d 626 (Del. Ch. 1961), motion for reargument denied, 177 A.2d 203, affd, 182 A.2d 907 (Del. Sup. Ct. 1962). These cases involved sales at an alleged premium for control of companies that were investment advisers to mutual funds. The Investment Company Act of 1940 provides for automatic termination of a management contract with the fund when the adviser's controlling shares are transferred. The Act requires a vote of the fund's shareholders to reinstate the contract. Investment Company Act of 1940 §\$ 2(a)(4), 15(a)(4), 15(b)(2), 54 Stat. 791, 812, 813 (1940), 15 U.S.C. $\S \S 80 a-2(a)(4), 80 a-15(a)(4), 80 a-15(b)(2)$ (1963). Krieger stated that sellers of controlling shares of the advisers who were also directors of the fund were liable for the excess over fair value, on the theory that they improperly used their positions as directors of the fund to insure reinstatement of the contract by use of the fund's proxy machinery. $173 \mathrm{~A} .2 \mathrm{~d}$ at 634 . But the seller was entitled to the premium attributable to "the good will element of value arising ... from the expectancy of renewal of the service contracts, at least in the hands of the sellers." Id. at 633. See also Note, Mutual Funds 
shares do not carry voting control, the seller should be liable for the premium, ${ }^{10 \pm}$ because the premium is just a payment for seriatim resignations. If there is no premium, seriatim resignations should be considered proper. When the directors negligently transfer board control to someone who harms the corporation, they should be liable for the actual damages whether or not they received any consideration.

Because the owner of shares that do not carry voting control cannot sell them for a premium and contract to provide seriatim resignations, neither should he be allowed to grant an option to purchase the shares for a consideration and also provide for immediate seriatim resignations. ${ }^{105}$ The value of the option, because of the probabilities in variation in value of the stock, is indeterminate. For this reason it is difficult to detect what portion of the consideration is attributable to the option and what is attributable to the payment for immediate board control.

Since the seller is liable for the premium on the sale of non-controlling shares coupled with a provision for seriatim resignations, the definition of "control" is crucial. Chief Judge Lumbard in Essex stated that the propriety of the provision for seriatim resignation depended upon whether the $28.3 \%$ of the outstanding shares could elect a majority of the directors at the next shareholder's meeting, assuming neutral proxy machinery. Of course the neutral proxy machinery restriction on the "working control" standard is correct; otherwise, for large, publicly held corporations ${ }^{106}$ working control would be held by management regardless of share ownership, thus justifying naked sales of offices.

Although the neutral proxy machinery requirement shifts the definition of working control from shareholder-director relationships ${ }^{107}$ to the relations of shareholders inter sese, there are obvious difficulties in administering a test based on the latter. Judge Friendly in his concurring opinion in Essex stated that were he on the New York Court of Appeals, he would sanction sales accompanied by a seriatim resignation only where

and the Investment Advisory Contract, 50 VA. L. Rev. 141, 149-54 (1964). This case is analogous to the situation where there is a payment to directors of the fund for transfer of offices in the fund without an underlying transaction in the stock of the fund. See text accompanying note 96 supra.

104 See note 88 supra for a definition of the premium.

105 For an example of seriatim resignations with an option to purchase the seller's shares, see In re Caplan's Petition, 20 App. Div. 2d 301, 246 N.Y.S.2d 913 (1964). The trial court blocked voting by the directors who had been installed by the assignee of the optionee on a proposed acquisition of other companies controlled by the assignee. The Appellate Division affirmed and vacated the seriatim resignations on the ground that control (3\%) was not involved. Id. at 303, 246 N.Y.S.2d at 915 (1964).

106 Hill, The Sale of Controlling Shares, 70 Harv. L. Rev. 986, 998 (1957).

107 See BerLe, Power Without Property 71 (Harvest ed. 1959). 
more than fifty per cent of the shares were sold. However, he advised purchasers of less than fifty per cent interests that they could always require that the sale be contingent upon an election of their nominees for the board at a special meeting of the shareholders. ${ }^{108}$ It is not clear whether he would require neutral proxy machinery at such a special meeting. To him the Lumbard test is unduly complex, requiring consideration of such factors as the proportion of shares held in street names, personality factors, ${ }^{109}$ dividend policies and possible stockholder disenchantment. ${ }^{110}$ The problems raised by Judge Friendly are substantial, and a formula for determining when shares alone carry control does not admit of easy or mathematical articulation. ${ }^{111} \mathrm{It}$ is probable, however, that in the mine run of cases these problems will not occur and that judges can quickly and easily decide the particular question. ${ }^{112}$ The Lumbard rule would minimize the risks imposed on the purchaser while management controlled by the seller remains entrenched, and would eliminate the necessity of costly notification of shareholders for a special election of directors at the purchaser's expense. The expectation that looting would be minimized by the Friendly approach seems of little merit if the purchaser can later elect directors in any case. The rule in detrimental sale cases would seem to afford sufficient protection from looting. ${ }^{113}$

\section{Premium for Control in Regapitalizations}

In a corporate recapitalization wherein a single class of common stock replaces two classes which are identical except that only one has voting rights, the principal problem is whether a premium for control should

$108305 \mathrm{~F} .2 \mathrm{~d}$ at 581.

109 " 'Working control" is . . complex because it involves an additional element which is in fact a quasi-political process. This element is the capacity to mobilize other shareholders." Berle, "Control" in Corporate Law," 58 Colum. L. REv. 1212, 1213 (1958).

110305 F.2d at 582.

111 But see Investment Company Act of 1940 \& 2(a)-(9), 54 Stat. $791-92$ (1940), 15 U.S.C. \& 80a-2(a)-(9) (1963) (rebuttable presumption that $25 \%$ carries control).

112 Any judicial standard that serves to resolve the easy cases can of course be criticized as fantasy. In light of the fact that a major function of corporation law is guidance, the purchasers in the "easy cases" should be encouraged to acquire board control by seriatim resignations to eliminate the expense of a neutral special election. The difficulties of indicating the outcome with neutral proxy machinery, especially when the burden of showing that the shares carried control, is properly placed on the purchaser. Note, Corporations: Sale of Control, 11 U.C.L.A.L. REv. 295, 298-99 (1964), would channel other proposed sales to the procedure suggested by Judge Friendlythat of making sale contingent upon election of the purchaser's nominees at a special meeting of the shareholders.

113 Comment, 37 N.Y.U.L. REv. 933, 942-43 (1962). 
be allowed to the voting shares. A related problem is whether a seller of the voting and, by definition, the controlling shares should be allowed to retain the premium.

Suppose first that the owner of the controlling voting shares sells them to a third party at a premium. When the voting shares are very few in relation to all common shares the transaction appears to be, in essence, a mere barter of corporate office. But there are obvious difficulties in articulating the basis and limits of a rule imposing liability for the premium on the seller of voting shares. If liability depends on whether the voting shares would constitute working control if the non-voting shares had voting rights, the basis of liability must be that the owner of the controlling voting shares does not have a sufficiently large monetary stake in relation to other investors in the company. If lack of monetary stake is indeed the criterion, there is a difficulty in distinguishing an ordinary sale of controlling shares for a premium and seriatim resignations when the corporation is highly leveraged with debt and preferred shares (which is proper in the absence of foreseeable detriment). Aside from the fact that practical considerations in the capital market limit the degree of leverage but not the percentage of non-voting shares, the risk of wrongdoing and the possibilities of benefits from sale to efficient management are equally great in both cases. Unless the law is to revert to a rule of liability without standards such as "barter of corporate offices" the premium should not be recoverable from the seller of controlling voting shares.

The Eighth Circuit in Honigman v. Green Giant Co.114 allowed a premium to the voting shares in a recapitalization. ${ }^{115}$ The defendant corporation had two classes of common stock outstanding: 44 shares of class A, and 428,998 shares of class B. The shares were identical in all respects, except that only class $A$ shares had voting rights. A plan of recapitalization, approved by 92.3 per cent of the class $B$ shareholders, created only one class of common stock and increased the participation of the class $\mathrm{A}$ in the equity from 0.01 per cent to 9.3 per cent. The plaintiff, a class $B$ shareholder, brought a class action to upset the plan. The court, limited to Minnesota law by its diversity jurisdiction, completely rejected the view of Professor Berle that a premium for control is a corporate asset, 116 and upheld the plan on the ground "that no fraud or inequitable conduct was resorted to in consummating the

114909 F.2d 667 (8th Cir. 1962).

115 Manacher v. Reynolds, 165 A.2d 741 (Del. Ch. 1960), is a case with facts and outcome substantially similar to Honigman.

116309 F.2d at 670 . 
amendment, 117 and the proposed plan was fair, equitable ${ }^{118}$ and beneficial both to the non-voting class B stockholders and to the corporation."119

In a recapitalization, as in the cases of prior offers for the purchase of all the assets ${ }^{120}$ and in reorganizations ${ }^{121}$ the argument for equal treatment of shareholders is a pleasing one. Equal treatment would appear desirable if the only possibility of benefit to the corporation was improved management. The facts of Honigman would indicate that no such changes were likely. The controlling owner of voting shares can properly be considered to have owned twenty per cent of the class $B$ shares and hence, probably retained working control after the recapitalization.122 Even if working control was not retained and the transaction characterized an arms-length sale of control to the class B shareholders, ${ }^{123}$ it is doubtful that existing management would be supplanted by a vote of the dispersed shareholders. ${ }^{124}$ In publicly-held corporations, the shareholders seldom can control management. ${ }^{225}$ But improved management is not the only class of economic benefit possibly flowing from the transaction. "Without voting stock, listing on a major exchange was blocked,

117 Compare Barrett v. Denver Tramway Corp., 53 F. Supp. 198 (D. Del.), aff'd, 146 F.2d 701 (3d Cir. 1944); Porges v. Vadsco Sales Corp., 27 Del. Ch. 127, 32 A.2d 148 (1943). The decision in Honigman cannot be said to rest on a judgment of the court that an adequate remedy for the dissenting shareholder was provided by appraisal rights. Such rights in Minnesota in the case of a charter amendment are limited to a substantial change in corporate purposes or an extension of the duration of the corporation. MiNN. SrAT. ANN. $\$ 301.40(1)$ (1947). Even where the appraisal remedy is available, the protection it provides is doubtful. Manning, The Shareholder's Appraisal Remedy: An Essay for Frank Coker, 72 YALE L.J. 223, 232-33 (1962).

118 Dodd, Fair and Equitable Recapitalizations, 55 HaRv. L. REv. 780 (1942); cf. Case v. Los Angeles Lumber Prods. Co., 308 U.S. 106, 122 (1939), which denied, in a plan of reorganization, a claim for participation by common shareholders based on "financial standing and influence" and "continuity of management." "Such items are illustrative of a host of intangibles which, if recognized as adequate consideration for the issuance of stock to valueless junior interests, would serve as easy evasions of the principle of full or absolute priority ...."

$119309 \mathrm{~F} .2 \mathrm{~d}$ at $671-72$.

120 See text accompanying note 58 supra.

121 See note 118 supra.

122 The trial court found the contrary. Honigman v. Green Giant Co., 208 F. Supp. 754, 765 (D. Minn. 1961). The plaintiff in Manacher v. Reynolds, 165 A.2d 741 (Del. Ch. 1960), also argued that the class $A$ retained working control, but the court responded "that the A may fairly exact a premium as a condition to the relinquishment of absolute voting control." 165 A.2d at 754.

123 Cf. Manacher v. Reynolds, supra note 122, at 755.

124 Apparently the existing management desired the recapitalization in Honigman to forestall "control falling into undesirable hands" on the death of the present controlling shareholder of class $A$, by imposing a higher capital requirement on such undesirables. Bayne, A Philosophy of Corporate Control, 112 U. PA. L. REv. 22, 45 n.67 (1963).

125 See Manning, Book Review, 67 Yale L.J. 1477 (1958). 
marketability hampered, and expansion opportunities, equity financing, and diversification by merger and acquisition were made more diffcult." 126

Thus the economic rationale for allowing the premium in cases of sales of control may be equally present in recapitalizations. ${ }^{127}$

Furthermore, if a premium is not allowed in recapitalizations, although it is properly allowable in cases of sales of voting shares, the net effect of the prohibition in recapitalizations will be to prevent their occurrence. The controlling owner of voting shares will prefer to sell them, in which case a premium is allowable. Prohibition of the premium in a recapitalization is a practical alternative only when the controlling shareholder and management are under a fiduciary duty of establishing the optimal capital structure, and are thus bound to propose a recapitalization. ${ }^{128} \mathrm{~A}$ rule of fiduciary duty to establish the best capital structure does not exist at present, however, because of fears of judicial interference with management. The courts scrutinize the transactions in capital structure when they occur. ${ }^{129}$ Because there is a possibility that non-controlling and nonvoting shares may not have the protection of arms-length dealing, judicial scrutiny for fraud and gross unfairness is desirable. ${ }^{130}$

\section{Conclusion}

The reluctance of the judiciary to impose a general rule of liability on sellers of controlling shares is basically sound. There is a strong possibility that a significantly large number of economically beneficial sales of control would be blocked by a rule that the seller is liable in all cases. Ipse dixit aside, the burden of establishing that a large proportion of purchasers are actuated by improper motives causing damages that cannot be restored by the imposition of liability on the purchaser has not been met, nor has any empirical support been adduced. Sellers of corporate control should be liable to the remaining shareholders only when they have sold under circumstances indicating a reasonable probability of economic detriment, and actual damages have occurred. If a recovery is made from the seller, he should be allowed an action over against the purchaser to recover his liability.

126 Bayne, supra note 124, at 45.

127 See text accompanying notes $11-16$ stupra.

128 Bayne, supra note 124 , at 49 , would impose this fiduciary duty.

129 Cf. United Funds, Inc. v. Carter Prods., Inc., 32 U.S.I. WeEr 2146 (Baltimore Cir. Ct. May 16, 1963), noted in 112 U. PA. L. Rev. 916 (1964). The court in United Funds held that a controlling shareholder breached his fiduciary duty to the minority by voting for a recapitalization of common stock into voting and non-voting shares, causing the minority to lose the benefits of stock exchange listing.

130 See Barrett v. Denver Tramway Corp., 53 F. Supp. 198 (D. Del.), aff'd, 146 F.2d 701 (3d Cir. 1944). 